University for Business and Technology in Kosovo

UBT Knowledge Center

UBT International Conference

2017 UBT International Conference

Oct 28th, 4:30 PM - 6:00 PM

\title{
Microbiological analysis of the Aspergillus carbonarius and Penicilliumverrucosum in Kosovo vineyards
}

\author{
Valon Durgati \\ University for Business and Technology \\ Aneliya Georgieva \\ University of Food Technologies \\ Galena Angelova \\ University of Food Technologies \\ Angel Angelova \\ University of Food Technologies \\ Zyri Bajrami \\ University of Tirana
}

Follow this and additional works at: https://knowledgecenter.ubt-uni.net/conference

Part of the Food Science Commons

\section{Recommended Citation}

Durgati, Valon; Georgieva, Aneliya; Angelova, Galena; Angelova, Angel; and Bajrami, Zyri, "Microbiological analysis of the Aspergillus carbonarius and Penicilliumverrucosum in Kosovo vineyards" (2017). UBT International Conference. 163.

https://knowledgecenter.ubt-uni.net/conference/2017/all-events/163

This Event is brought to you for free and open access by the Publication and Journals at UBT Knowledge Center. It has been accepted for inclusion in UBT International Conference by an authorized administrator of UBT Knowledge Center. For more information, please contact knowledge.center@ubt-uni.net. 


\title{
Microbiological analysis of the Aspergillus carbonarius and Penicillium verrucosum in Kosovo vineyards
}

\author{
Valon Durguti ${ }^{1 *}$, Aneliya Georgieva ${ }^{2}$, Galena Angelova ${ }^{2}$, Angel Angelov ${ }^{2}$, Zyri Bajrami ${ }^{3}$ \\ $1 *$ UBT - Higher Education Institution, Lagjja KALABRIA p.n., Prishtinë, Kosovë \\ 10000 Prishtina, Kosovo \\ ${ }^{2}$ University of Food Technologies - Departament of Biotechnology, Food Safety \\ and Microbiology, Plovdiv - Bulgaria \\ ${ }^{3}$ University of Tirana, Departament of Biology, Tirana -Albania \\ valon.durguti@ubt-uni.net
}

\begin{abstract}
Through the use of the microbiological semi-selective media (MEA-B and DYSG) for the species Aspergillus carbonarius and Penicillium verrucosum we have analyzed different varieties of the table and wine grapes in the region of Suhareka, south part of Kosovo. The purpose of this scientific work it was to determine through the microbiological analysis the main species of the fungi that produce the micotoxin known as Ochratoxin A. Analysis of the samples was done in the Department of Microbiology, University of Food and Technology, Plovdiv Bulgaria.
\end{abstract}

Keywords: grape, fungi, microbiology, ochratoxin A, mycotoxin

\section{INTRODUCTION}

Fungi in their cellular organization are clearly eukaryotes and for that are now recognized as one of the five eukaryotic kingdoms.

Different kinds of large fungi or macrofungi have been recognized for thousands of years but in the early nineteenth it was established that many serious plant diseases were caused by infection of the plant by minute living organisms, recognized as microscopic fungi or microfungi. Microfungi were also found attracking dead organic materials and they were termed moulds, spelt molds in USA [6].

Molds are filamentous fungi that are classified based on the morphology of asexual or vegetative mycelia elements and their spore structures. Molds are ubiquitous with various genera commonly found on grapes, examples include Aspegillus, Botrytis and Penicillium, and to a lesser extent Phytophtora, Moniliella, Alternaria and Cladosporium [5].

The growth of fungi in a particular food is governed largely by a series of physical and chemical parameters (water activity, temperature, nutrient status, $\mathrm{pH}$, preservatives, etc), and these factors do not act independently, but synergistically [11]. 
The greatest risk from the growth of fungi on fruit (grapes) is their ability to synthesize in the optimal conditions the substances (secondary metabolites) known as micotoxins, which are very dangerous to human health, animals and plants [3].

Ochratoxin A, N-[(3R)-(5-chloro-8-hydroxy-3-methyl-1-oxo-7-isochromanyl) carbonyl]-L-phenylalanin is a mycotoxin produced by certain species of Aspergillus and Penicillium filamentous fungi. OTA contaminates cereals and cereal products, coffee, beans, pork meat and meat products, milk and milk products, eggs, wine and beer all over the world [2].

The Penicillium species that is associated with ochratoxin A production is Penicillium verrucosum, which is considered to be the largest producer of OTA in cereals, such as wheat, oats, barley and rye, in areas where the cold climate prevails [7]. It grows only at temperatures below $30^{\circ} \mathrm{C}$ and at a lower water activity. Penicillium species may produce ochratoxin A at temperatures as low as $5^{\circ} \mathrm{C}[1]$.

Aspergillus ochraceus is the best known species of ochratoxin A - producing Aspergillus. It grows at moderate temperatures and at a high water activity and is a significant source of ochratoxin A in cereals. It infects coffee beans usually during sun-drying causing contamination in green coffee [1].

Aspergillus carbonarius is highly resistant to sunlight and survives sun-drying because of its black spores and therefore grows at high temperatures. It is associated with maturing fruits and is the source of ochratoxin A in grapes, dried vine fruits, and wine and is also another source of ochratoxin A in coffee [1].

Aspergillus niger is another minor source of ochratoxin A production in infected coffee beans and dried vine fruits.

Mycotoxins can cause serious health problems in animals and humans known as mycotoxicosis [4] . The mycotoxin has been detected in various food stuffs such as dried fruits, coffee, maize, sorghum, wheat, pulses and wine [10]. The toxic effects of mycotoxins (e.g. ochratoxins, fumonisins, zearalenone, etc.) are mostly known from veterinary practice. Mycotoxicoses, which can occur in both industrialized and developing countries, arise when environmental, social and economic conditions combine with meteorological conditions (humidity, temperature) which favour the growth of moulds [8].

The OTA levels in grape and wine depend on different factors such as the climate, the date of harvesting and different wine-making procedures. Climatic conditions (high humidity and temperature) and geographical location are important factors favouring OTA accumulation in grape berries [13].

OTA exposure has been associated with increased levels of oxidative DNA, lipid, and protein damage. Second, various biological processes known to be mobilized under oxidative stress were shown to be altered by OTA. These effects have been observed in both in vitro and in vivo test systems. In vivo, active doses were often within doses documented to induce renal tumors in rats [9].

OTA is arguably risk factor for Balkan Endemic Nephropathy (BEN). BEN is a chronic tubulointerstitial kidney disease that occurs in some areas of Bosnia and Herzegovina, Bulgaria, Croatia, Romania, Serbia, and Monte Negro [14]. 
International Agency for Cancer Research classifies OTA as potential carcinogenic substance for man (group 2B). Zimmerli and Dick (1995) were the first ones to report the existence of OTA in grape and wine [15].

\section{MATERIALS AND METHODS}

For isolation and microbiological analysis of these two types of the fungi responsible for synthesizing of ochratoxin A (Aspergilus carbonarius and Penicillium verrucosum) we have used the recommendations given by ICFM - International Comission of Food Mycology [11].

We have applied two kinds of methods for cultivation and isolation of the fungi: a) direct plating and b) dilution plating.

In the beginning of the work we have prepared the semi - selective media, MEA - B (Malt Extract Agar - Boscalid) for cultivation and potential isolation of the fungi known as Aspergillus carbonarius and DYSB (Yeast Extract Sucrose Glycerol Agar) for cultivation and potential isolation of the fungi known as Penicillium verrucosum.

a. The composition of the microbiological semi-selective media MEA-B (Malt Extract Agar Boscalid)

- $\quad$ Malt Extract 20 g/1, LOT: BCBQ0197V - Fluka Company (Sigma Aldrich) - France

- $\quad$ Agar 20 g/l, Fillab - EOOD

- Chloramphenicol $0.005 \mathrm{~g} / \mathrm{l}$, Fillab - EOOD

- Dichloran $1.0 \mathrm{ml}(0.2 \%)$, LOT: STBF2742V, Sigma Aldrich

- $\quad$ Boscalid 10 mg/l, LOT: SZBF099XV - Fluka Company (Sigma Aldrich) - Germany

- $\quad$ Pepton 0.1\%, LOT: 63927JD, Difcolaboratories

- $\quad$ Ethanol $70 \%$

- $\quad \mathrm{H} 201000 \mathrm{ml}$

b. The composition of the microbiological semi-selective media DYSG (Yeast Extract Sucrose Glycerol Agar)

- $\quad$ Yeast extract 20 g/l, LOT: BCBQO966V, Fluka Company (Sigma Aldrich) -France

- $\quad$ Sucrose $150 \mathrm{~g}$, Fillab - EOOD

- $\quad$ K2HPO4 1 g, Fillab - EOOD

- $\quad \mathrm{MgSO} 4+2 \mathrm{H} 20$ 0.5g, Fillab - EOOD

- Chloramphenicol 2 x 0.05 g, Fillab - EOOD

- $\quad$ Dichloran 1.0 ml, LOT: STBF2742V, Sigma Aldrich

- $\quad \mathrm{ZnSO} 4+2 \mathrm{H} 20 \quad 0.01 \mathrm{~g}$, Fillab - EOOD

- $\quad \mathrm{CuSO} 4+5 \mathrm{H} 20 \quad 0.005 \mathrm{~g}$, Fillab - EOOD

- $\quad$ Agar 20 g, Fillab - EOOD

- Glycerol 220 ml, LOT: SZBFO62DV, Sigma Aldrich

- $\quad$ Pepton 0.1\%, LOT: 63927JD, Difcolaboratories

- $\quad$ Ethanol $70 \%$

- H20 $1000 \mathrm{ml}$ 


\section{DIRECT PLATING}

\section{.Sample preparation}

After semi - selective media preparation and their sterilization in autoclave with steam pressure at $121{ }^{\circ} \mathrm{C}$ for 15 minutes, the grapes of different varieties are disinfected first with alcohol (ethanol $70 \%$ ) for 2 minutes and then are washed (cleared) with water for 1 minute.

The analyzed varieties were: Sauvignon Blanc, Gamay, Franconia, Pinot Blanc and Muscat Hamburg.

The grape plating is done in sterile box, part of the microbiological laboratory in the University of Food Technologies, Plovdiv - Bulgaria.

\section{PLATING}

After sample preparation, we have taken 4 grape berries from each variety and set them into the Petri dishes, three replicates for each one. After deciding the grape berries into the Petri dishes, all of the samples are placed in an incubator, in the temperature $25^{\circ} \mathrm{C}$ for 5 day.

\section{Examination}

After incubation phase, initially we have made a visual examination of the Petri dishes through the appropriate lenses, counted the infected grape berries and the results are presented as a percentage. After that, through the use of the microscope we have made microscopic analysis, for the purpose of greater security during identification and analysis of certain characteristics of the analyzed species. Microscopic examination is done by taking a handful of developed fungi colonies and their placement by microbiological needle in the microscope slide. Then we have thrown a drop of alcohol (ethanol 70\%) in the microscopic sample, left the alcohol to evaporate and finally we have thrown a drop of lactic acid, covered the sample with cover slide and thus the sample was ready for microscopic examination.

\section{Dilution plating}

\section{Sample preparation}

ICFM - International Comission of Food Micology (I.Pitt.J and D.Hocking.A, 2006) recommends two usual methods for sample preparation (homogenization) in the initial stage of the dilution plating: a) through the homogenizer known as stomaching machine and b) through the homogenizer known as blending machine.

We have used a blending machine (BEER), but in advance grape berries as well as other methods are treated with alcohol (ethanol 70\%) for 2 minutes and then washed (cleared) by water for 1 minute.

\section{Diluents and dilution}

In this study work we have used aqueous solution of peptone $0.1 \%$. We have prepared a series of dilutions recommended by ICFM, while for inoculation we have used dilutions of $10^{-3}-10^{-5}$, three dilutions for each variety and each semi - selective media. After the preparation a series of 
dilutions, we have taken a drop $(0.1 \mathrm{ml})$ from a series of test tubes $\left(10^{3}-10^{-5}\right)$ and have thrown it in the Petri dishes, in both semi - selective media. Then through microbiological shoulder we have distributed the material (drop) uniformly through the semi - selective media. Shoulder in each case is treated with alcohol (70\% ethanol) and then sterilized with flame.

At the end the Petri dishes are placed in an incubator, in temperature $25^{\circ} \mathrm{C}$ for 5 day. The results of this method (method of dilution) are presented as well as for bacteria, as colonies per gram of analyzed sample (viable counts / gram of the sample). Even to this method as well as to direct plating, after completion of the incubation the samples are examined under a microscope, previously treated with alcohol (ethanol 70\%) and lactic acid in microscope slide.

\section{Results and discussion}

Table 1.The percentage (\%) of moulds infection in the five grape varieties (Direct Plating in MEA-B)

\begin{tabular}{|c|c|c|c|c|}
\hline MEA - B & $\begin{array}{c}\text { The Petri Dish } \\
\text { nr. 1 }\end{array}$ & $\begin{array}{c}\text { The Petri Dish } \\
\text { nr. 2 }\end{array}$ & $\begin{array}{c}\text { The Petri Dish } \\
\text { nr. 3 }\end{array}$ & Average \% \\
\hline $\begin{array}{c}\text { Sauvignon } \\
\text { Blanc }\end{array}$ & 25 & 25 & 25 & $25 \%$ \\
\hline Gamay & 43,75 & 25 & 25 & $31,25 \%$ \\
\hline Franconia & 25 & 31,25 & 25 & $27,08 \%$ \\
\hline Pinot Blanc & 37,5 & 25 & 25 & $29,17 \%$ \\
\hline $\begin{array}{c}\text { Muscat } \\
\text { Hamburg }\end{array}$ & 6,25 & 6,25 & 43,75 & $18,75 \%$ \\
\hline
\end{tabular}

From the obtained results from the direct and dilution plating in the semi-selective media MEA - B we have seen the pronounced presence of the genera Alternaria and other kinds of the moulds, as well as lack of the genera Aspergillus (Aspergillus carbonarius) and Penicillium (Penicillium verrucosum).

Based on the results (\% of the infection) presented in the tab.1. we can see that in any of the analyzed grape varieties by direct plating, the percentage of infection does not exceed $50 \%$ and this probably as a result of applying the appropriate process of splashing the grapes with fungicides in vineyards where sampling is done. 
Table 2. The total number of colonies (Dilution Plating in MEA-B)

\begin{tabular}{|c|c|c|c|c|c|c|}
\hline \multicolumn{7}{|c|}{ The total number of colonies in each dilution } \\
\hline \multirow[t]{2}{*}{$\mathrm{MEA}-\mathrm{B}$} & \multicolumn{2}{|c|}{$10^{-3}$} & \multicolumn{2}{|l|}{$10^{-4}$} & \multicolumn{2}{|c|}{$10^{-5}$} \\
\hline & 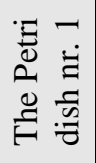 & 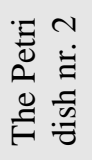 & 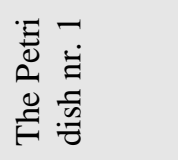 & 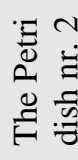 & 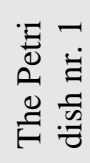 & 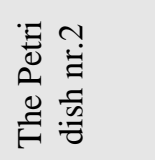 \\
\hline $\begin{array}{c}\text { Sauvignon } \\
\text { Blanc }\end{array}$ & 19 & 15 & 3 & 2 & - & - \\
\hline Gamay & 24 & 28 & 6 & 2 & - & $\begin{array}{l}2 \text { (2 fungi } \\
\text { colonies) }\end{array}$ \\
\hline Franconia & 3 & 1 & - & - & - & - \\
\hline Pinot Blanc & 6 & 11 & 1 & - & - & 3 \\
\hline $\begin{array}{c}\text { Muscat } \\
\text { Hamburg }\end{array}$ & 41 & 25 & $\begin{array}{l}\text { (1fungi } \\
\text { colonies) }\end{array}$ & 7 & - & 3 \\
\hline
\end{tabular}

From the results of the tab.2. we can see that the dilution to the extent of 10-3 is suitable for the cultivation of moulds of different genres compared to the level of other dilutions, in terms of total number of colonies expressed after the incubation phase.

Table 3. Morphological charachteristics of the moulds isolated in MEA-B (Direct Plating)

\begin{tabular}{|c|c|c|c|c|c|}
\hline \multicolumn{2}{|c|}{$\begin{array}{l}\text { The cultures } \\
\text { characteristics }\end{array}$} & \multicolumn{2}{|c|}{ The morphological characteristics } & \multirow[t]{2}{*}{ Gender } & \multirow[t]{2}{*}{ Variety } \\
\hline $\begin{array}{l}\text { The } \\
\text { colony } \\
\text { colour }\end{array}$ & $\begin{array}{c}\text { The } \\
\text { pigmentation } \\
\text { presence }\end{array}$ & Hyphae & Spores & & \\
\hline $\begin{array}{l}\text { Gray- } \\
\text { white } \\
\text { colony }\end{array}$ & $\begin{array}{l}\text { Dark brown } \\
\text { to black } \\
\text { pigmentation }\end{array}$ & Hyphae - septated & $\begin{array}{l}\text { Brown, } \\
\text { septated } \\
\text { with } \\
\text { pyriform } \\
\text { shape }\end{array}$ & Alternaria & $\begin{array}{c}\text { Gamay } \\
\text { Franconia } \\
\text { M. Hamburg } \\
\text { Sauvignon Blanc }\end{array}$ \\
\hline $\begin{array}{l}\text { Olive } \\
\text { green } \\
\text { colony }\end{array}$ & $\begin{array}{l}\text { Black } \\
\text { pigmentation }\end{array}$ & Hyphae - septated & $\begin{array}{l}\text { Green, } \\
\text { lemon- } \\
\text { shaped }\end{array}$ & Cladosporium & $\begin{array}{c}\text { Franconia } \\
\text { Sauvignon Blanc }\end{array}$ \\
\hline $\begin{array}{l}\text { Light to } \\
\text { dark } \\
\text { brown }\end{array}$ & $\begin{array}{l}\text { Brown } \\
\text { pigmentation }\end{array}$ & $\begin{array}{c}\text { Septated, walls are } \\
\text { thick }\end{array}$ & $\begin{array}{c}\text { Not } \\
\text { determined }\end{array}$ & Not determined & Gamay \\
\hline $\begin{array}{l}\text { White } \\
\text { colony }\end{array}$ & $\begin{array}{l}\text { No } \\
\text { pigmentation }\end{array}$ & Hyphae - septated & $\begin{array}{c}\text { Not } \\
\text { determined }\end{array}$ & Not determined & $\begin{array}{l}\text { Gamay } \\
\text { Franconia }\end{array}$ \\
\hline $\begin{array}{l}\text { Dark } \\
\text { brown } \\
\text { to black } \\
\text { colony }\end{array}$ & $\begin{array}{l}\text { Yellow } \\
\text { pigmentation }\end{array}$ & Hyphae - septated & $\begin{array}{l}\text { Conidia - } \\
\text { brown, oval }\end{array}$ & $\begin{array}{l}\text { Aspergillus } \\
\text { carbonarius }\end{array}$ & M. Hamburg \\
\hline
\end{tabular}


Of particular importance is the fact that we have isolated at the grape variety Muscat Hamburg a colony which according to the morphological characteristics belongs to the genera Aspergillus, concretely the Aspergillus carbonarius (fig.1.). During the work we have used in the MEA-B the fungicide called boscalide, which inhibits the growth and development of other species of the Aspergillus and allows only the growth of the Aspergillus carbonarius.

Table 4.The percentage (\%) of moulds infection in the five grape varieties (Direct Plating in DYSG)

\begin{tabular}{|c|c|c|c|c|}
\hline DYSG & $\begin{array}{c}\text { The Petri dish } \\
\text { nr. 1 }\end{array}$ & $\begin{array}{c}\text { The Petri dish } \\
\text { nr. 2 }\end{array}$ & $\begin{array}{c}\text { The Petri dish nr. } \\
3\end{array}$ & Average \% \\
\hline $\begin{array}{c}\text { Sauvignon } \\
\text { Blanc }\end{array}$ & 6,25 & 0 & 0 & $2,08 \%$ \\
\hline Gamay & 25 & 6,25 & 6,25 & $12,5 \%$ \\
\hline Franconia & 6,25 & 25 & 12,5 & $14,58 \%$ \\
\hline Pinot Blanc & 0 & 18,75 & 0 & $6,25 \%$ \\
\hline $\begin{array}{c}\text { Muscat } \\
\text { Hamburg }\end{array}$ & 12,5 & 0 & 0 & $4,17 \%$ \\
\hline
\end{tabular}

Based on the results (\% of the infection) presented in the tab.4 we can see that also here like in the tab. 1 in any of the analyzed grape varieties by direct plating in the semi - selective media DYSG the percentage of infection does not exceed 50\% and the infection rate here is lower compared with the infection in semi - selective media known as MEA - B.

Table 5. The total number of colonies (Dilution Plating in DYSG)

\begin{tabular}{|c|c|c|c|c|c|c|}
\hline \multicolumn{7}{|c|}{ The total number of colonies for each dilution } \\
\hline DYSG & \multicolumn{2}{|c|}{$10^{-3}$} & \multicolumn{2}{c|}{$10^{-4}$} & \multicolumn{2}{c|}{$10^{-5}$} \\
\hline & $\begin{array}{c}\text { The Petri } \\
\text { dish nr. 1 }\end{array}$ & $\begin{array}{c}\text { The Petri } \\
\text { dish nr. 2 }\end{array}$ & $\begin{array}{c}\text { The Petri } \\
\text { dish nr. 1 }\end{array}$ & $\begin{array}{c}\text { The Petri } \\
\text { dish nr. 2 }\end{array}$ & $\begin{array}{c}\text { The Petri } \\
\text { dish nr. 1 }\end{array}$ & $\begin{array}{c}\text { The } \\
\text { Petri } \\
\text { dish nr.2 }\end{array}$ \\
\hline $\begin{array}{c}\text { Sauvignon } \\
\text { Blanc }\end{array}$ & 9 & 14 & 2 & - & - & - \\
\hline Gamay & 5 & 5 & - & - & - & - \\
\hline Franconia & 1 & - & - & 2 & - & - \\
\hline $\begin{array}{c}\text { Pinot } \\
\text { Blanc }\end{array}$ & 7 & 6 & - & - & 1 & - \\
\hline $\begin{array}{c}\text { Muscat } \\
\text { Hamburg }\end{array}$ & 27 & 26 & 3 & 2 & - & 4 \\
\hline
\end{tabular}

As well as in the tab. 2 we can see also here that the dilution to the extent of $10^{-3}$ is suitable for the cultivation of moulds of different genres compared to the level of other dilutions. 
Table 6. Morphological charachteristics of the moulds isolated in DYSG (Direct Plating)

\begin{tabular}{|l|c|c|l|c|c|}
\hline \multicolumn{2}{|c|}{ The culture characteristics } & \multicolumn{2}{|c|}{$\begin{array}{c}\text { The morphological } \\
\text { characteristics }\end{array}$} & Gender & Variety \\
\hline $\begin{array}{l}\text { The colony } \\
\text { colour }\end{array}$ & $\begin{array}{c}\text { The } \\
\text { presence of } \\
\text { pigmentation }\end{array}$ & Hypha & Spore & & \\
\hline Gray-white & $\begin{array}{l}\text { Dark brown } \\
\text { to black } \\
\text { pigmentation }\end{array}$ & $\begin{array}{c}\text { Hyphae - } \\
\text { septated }\end{array}$ & $\begin{array}{l}\text { Brown, } \\
\text { septated with } \\
\text { pyriform } \\
\text { shape }\end{array}$ & $\begin{array}{c}\text { Alterna } \\
\text { ria }\end{array}$ & $\begin{array}{c}\text { Gamay } \\
\text { Francon } \\
\text { ia }\end{array}$ \\
\hline Brown & & $\begin{array}{c}\text { Hyphae - } \\
\text { septated } \\
\text { and thick } \\
\text { walls }\end{array}$ & Oval shape & $\begin{array}{c}\text { Not } \\
\text { determi } \\
\text { ned }\end{array}$ & $\begin{array}{c}\text { Francon } \\
\text { ia }\end{array}$ \\
\hline
\end{tabular}

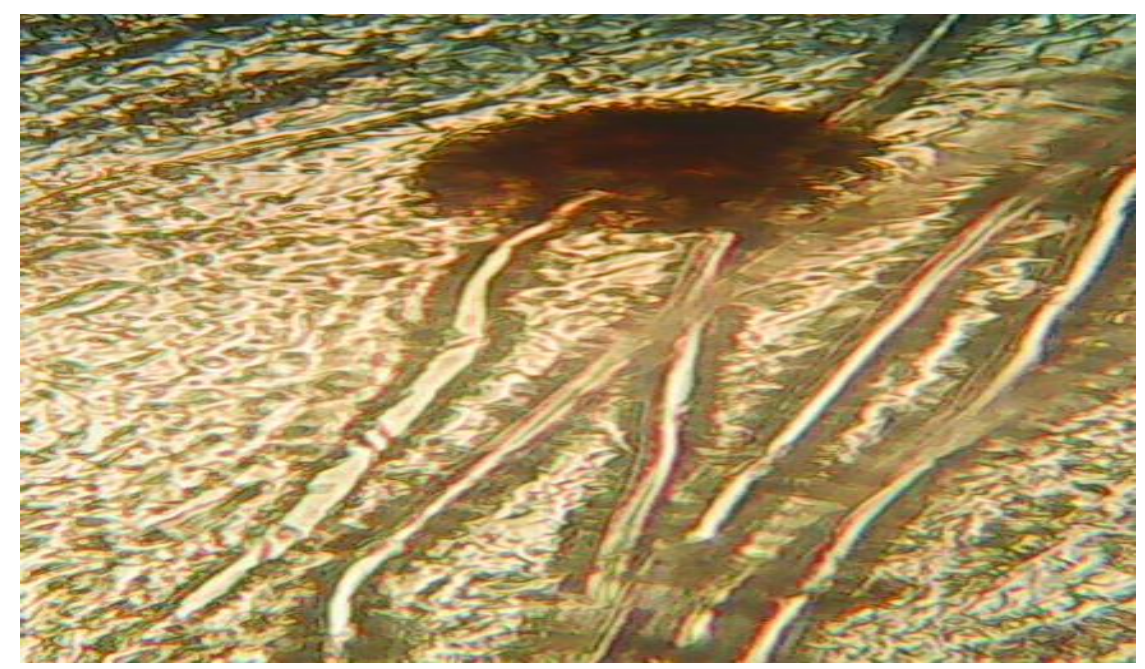

Fig.1. Aspergillus carbonarius isolated in the variety Muscat Hamburg (MEA-B), SuharekaKosovo

\section{CONCLUSIONS}

After completing of this study work we can conclude that the main species of the fungi responsible for OTA synthesis (Aspergillus carbonarius and Penicillium verrucosum) appear in very small extent in the vineyards which we have analyzed, or specifically in only one case and that to the type of the table grape known as Muscat Hamburg.

This probably is due to climatic conditions not so favorable for the growth and development of the fungi responsible for the OTA synthesis in Kosovo, or due to adequate application of the splashing process in the analyzed vineyards with substances known as fungicides.

From the obtained results we can see the slightly greater presence of the genera Alternaria and that in both semi - selective media (MEA-B and DYSG).Then we can see the presence of the 
genera Cladosporium only in the MEA-B, this typical for grape together with genera Alternaria, as well as other types of microorganisms.

In the future it would be of particular interest to study the effect of the fungicides in the species responsible for synthesizing of OTA in grapes (Aspergillus carbonarius and Penicillium verrucosum). Concretely, to analyse in microbiological or genetic way these two species in the grape samples, previously treated with fungicide and then untreated with fungicide, in order to confirm the potential effect of the fungicides in these main species of the fungi responsible for the OTA synthesizing.

We can finally conclude that the citizens of Kosovo are not endangered by the consumption of the table and industrial grapes, also the consumption of the wines produced from these grape varieties, in the sense of intoxication with micotoxin known as ochratoxin A (OTA).

\section{REFERENCES}

1. Centre for Food Safety, Food and Environmental Hygiene Department, The Government of the Hong Kong Special Administrative Regiondried vine fruits: Ochratoxin A in Food.(2006) Report nr.23; available at: http://www.cfs.gov.hk/

2. D.Flajs, A-M.Domijan, D.Ivić, B.Cvjetković and M.Peraica: ELISA and HPLC analysis of ochratoxin A in red wines of Croatia, (2009) Food Control; 590 - 592.

3. E.Zain., M: Impact of mycotoxins on humans and animals. Journal of Saudi Chemical Society, Volume 15, Issue 2, (2011) Pg: 129-144.

4. El Khoury, A., and Atoui, A: Ochratoxin A: General Overview and Actual Molecular Status. Toxins 2(4): (2010) 461-493.

5. Fugelsang.K and Edwards.Ch. : Wine Microbiology, (2007),USA.

6. J Carlile M., Dr, C Watkinson S., and W Gooday G.: The Fungi (Second Edition), Copyright (c) 2001 Elsevier Ltd.

7. Javier Cabañes F., Rosa Bragulat M., and Castellá G: Ochratoxin A Producing Species in the Genus Penicillium. Toxins (Basel); (2010) 2(5): 1111-1120.

8. M. Peraica., B. Radic., A. Lucic., and M. Pavlovic: Toxic effects of mycotoxins in humans, Bulletin of the World Health Organization, (1999) 77 (9).

9. Marin-Kuan M., Ehrlich V., Delatour T., Cavin C., and Schilter B: Evidence for a Role of Oxidative Stress in the Carcinogenity of Ochratoxin A. Journal of Toxicology (2011) 645361 .

10. Marquardt R.R., Frohlich A.A. (1992): A review of recent advances in understanding ochratoxicosis. PubMed J Anim.Sci. (1992) 70 (12), 3968-88.

11. Pitt J.I. and Hocking A.D: Fungi and Food Spoilage, (2009) Springer, USA.

12. Ribereau-Gayon.P., Dubourdie D., Doneche B., and Lonvaud A: Handbook of Enology, Volume 1, The Microbiology of Vine and Vinifications 2-nd Edition, (2006), France.

13. Visconti. A., Perrone. G., Cozzi. G. and Solfrizzo., M: Managing ochratoxin A risk in the grape-wine food chain, Food Additives \& Contaminants; (2008) 193-202.

14. Yordanova, P., Wilfried, K., and Dimitrov, P. (2010): Ochratoxin A and $\beta 2$ Microglobulin in BEN Patients and Controls. Journal List Toxins (Basel), (2010) V2 (4).

15. Zimmerli B. and Dick R: Ochratoxin A in table wine and grape-juice: Occurrence and risk assessment. Food Additives and Contaminants (1996) 13, 655-668 